\section{DIARY}

GDC events: Maintaining quality and impact: CPD in UK dentistry Date: 17 April 2012

Venue: Royal Institute of British Architecture, London, 10am-4pm www.gdc-uk.org

Prion infectivity in the oral cavity Date: 26 April 2012, 9.30am-4pm Venue: The Roslin Institute Auditorium, Easter Bush Veterinary Campus, University of Edinburgh Email: gila.holiman@roslin.ed.ac.uk www.stn.ed.ac.uk/stn/seminars.html

British Dental Conference and Exhibition 2012 Date: 26-28 April 2012 Venue: Manchester Central Convention Complex www.bda.org/conference

The British Society for Restorative Dentistry Spring Scientific Meeting Date: 4-5 May 2012

Venue: The University Arms Hotel, Cambridge

Email: matthew.garrett@nhs.net www.bsrd.org.uk

\section{The Clinical Innovations}

Conference 2012

Date: 18-19 May 2012

Venue: The Millennium Gloucester

Hotel and Conference Centre, London Telephone: 02074008989

Email:info@smile-on.com www.clinicalinnovations.co.uk

Scottish Dental Show 2012

Date: 24-25 May 2012

Location: Hampden Park, Glasgow www.scottishdentalmag.co.uk/show

11th Congress of the European Academy of Paediatric Dentistry A Crossroads of Knowledge, Innovation and Expertise Date: 24-27 May 2012 Venue: Convention Centre, Strasbourg, France www.eapd2011.eu

118th Meeting of the American Dental Society of Europe Date: 28-30 June 2012

Location: Vienna, Austria Telephone: Dr Lloyd Searson, 02076374518

www.ads-eu.org

\title{
VULNERABLE YOUTH OF TOWER HAMLETS RECRUITED FOR DENTAL NURSING
}

Neil Sikka of Barbican Dental Care in London has created the iNSkills initiative which will provide disaffected youth in the Tower Hamlets area with the opportunity to achieve an NVQ Level 3 qualification in dental nursing.

Working in conjunction with the local council, college and other practices in the City of London and Canary Wharf, the initiative will provide training and real job prospects for a vulnerable group.

'Within the Square Mile there are some of the most successful businesses and the richest people. But just outside is Tower Hamlets, the poorest borough in the UK,' said Dr Sikka. 'We wanted to create a scheme where we could offer people the chance of training, work and, more importantly, career development.'

The pilot scheme, launched in February 2012, has sourced eight trainees from the borough of Tower Hamlets. Tower Hamlet Council's Skillsmatch - an outreach team with established links in the community - sourced the candidates and will mentor the trainees throughout the duration of the course. Tower Hamlets College will provide the training on a day-release basis and students will gain work experience and valuable on-the-job training.

The initiative includes an 'earn as you learn' element, where students will be paid for their working and college time.

Dr Sikka now plans to roll out the programme to other practices within and adjacent to Tower Hamlets. Any interested practice owners can contact Dionne Marsh at dee.m@barbicandentalcare.com.

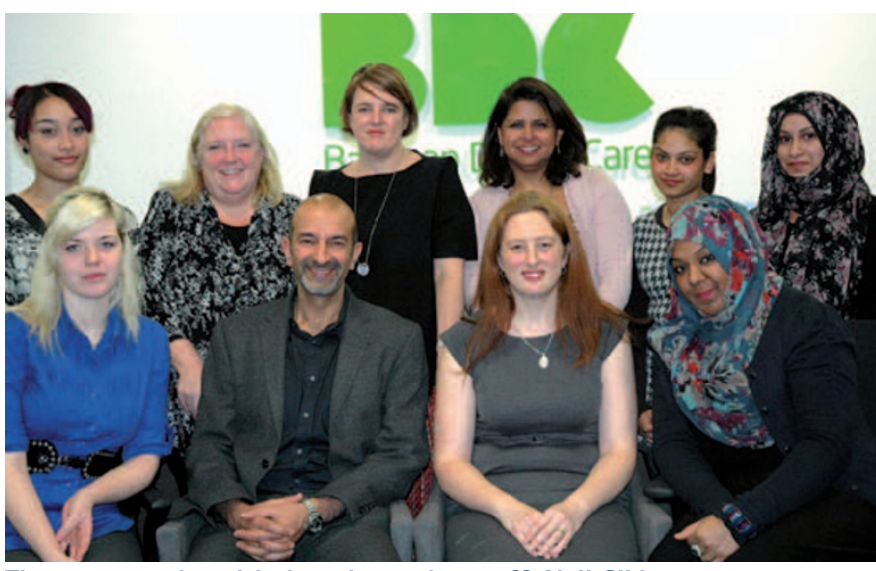

The new recruits with dental practice staff, Neil Sikka (front row) and Clare Coombe of Skills Match (front row, 2nd from right)

\section{COW COLLAGEN HEALS GUMS}

New research published in open access journal Head at Face Medicine demonstrates that bovine collagen can enhance gum healing. ${ }^{1}$

Researchers in Germany and Switzerland investigated the possibility of using collagen extracted from bovine pericardium (the fluid filled sac that surrounds the heart) to form a support for mending receding gums and exposed roots. The collagen was extracted by a process involving osmotic, oxidative and alkaline treatment to ensure that the cell walls were broken down, proteins and fats dissolved, and that bacteria, viruses and other pathogens were inactivated and removed.

The study followed 14 otherwise healthy patients with over 60 gum 'recessions' between them. Their damaged teeth were cleaned before surgery and the collagen implants held in place with loops of surgical thread around the affected tooth. Two weeks later the sutures were removed. None of the patients needed antibiotics.

The patients were re-examined after six months to see how well they had recovered.
'In all cases the healed-over implant improved the look and severity of the recession and, in over half of all treatments, resulted in total coverage of the exposed root,' said Dr Markus Schlee, who led the investigation with $\mathrm{Dr}$ Shahram Ghanaati. 'We would not have expected any of these patients to get better without surgery.'

The collagen seems to be able to act as a scaffold for the body's own cells to repair the damage leading to results on a level comparable to that of connective tissue grafts. Bovine collagen is a possible solution for patients with little available donor tissue or for whom multiple surgeries are not an option.

1. Schlee $M$, Ghanaati $S$, Willershausen I, Stimmlmayr M, Sculean A, Sader R A. Bovine pericardium based non-cross linked collagen matrix for successful root coverage, a clinical study in human. Head Face Med 2012: 8: doi:10.1186/1746-160X 